\title{
(3) Assessment of Human Islet Composition and Acinar Cell Component by Immunofluorescence Staining $V .1$
}

\author{
IIDP-HIPP ${ }^{1}$

\section{${ }^{1}$ Integrated Islet Distribution Program and Human Islet Phenotyping Program} \\ Integrated Islet Distribution Program and Human Islet Phenotyping \\ Program \\ Tech. support email: heather.durai@vumc.org
}

VERSION 1

FEB 10, 2021

\section{open $\mathcal{O}$ access}

DOI:

dx.doi.org/10.17504/protocol s.io.brdfm23n

Protocol Citation: IIDP-HIPP 2021. Assessment of Human Islet Composition and Acinar Cell Component by Immunofluorescence Staining. protocols.io

https://dx.doi.org/10.17504/p rotocols. io. brdfm $23 n$

License: This is an open access protocol distributed under the terms of the Creative Commons Attribution License, which permits unrestricted use, distribution, and reproduction in any medium, provided the original author and source are credited

Protocol status: Working We use this protocol and it's working

Created: Jan 12, 2021

Last Modified: Feb 10, 2021

PROTOCOL integer ID: 46215
IIDP-HIPP

\section{ABSTRACT}

This Standard Operating Procedure (SOP) is based on the Vanderbilt Human Islet Phenotyping Program Core Facility (VHIPP) Immunofluorescence Staining Procedure. This SOP provides HIPP procedure for immunofluorescent staining, imaging, and analysis of islet preparations.

This SOP defines the assay method used by the Human Islet Phenotyping Program (HIPP) for quantitative and qualitative determination of the Purified Human Pancreatic Islet product, post-shipment, manufactured for use in the National Institute of Diabetes and Digestive and Kidney Diseases (NIDDK)-sponsored research in the Integrated Islet Distribution Program (IIDP).

Note

This Standard Operating Procedure (SOP) \#: HIPP-07-v02

\section{GUIDELINES}

- Integrated Is/et Distribution Program (IIDP) (RRID:SCR_014387): The IIDP is a grant funded program commissioned and funded by the NIDDK to provide quality human islets to the diabetes research community to advance scientific discoveries and translational medicine. The IIDP consists of the NIDDK Project 
Keywords: Human Islet Composition, Acinar Cell Component, Immunofluorescence Staining, HIPP, IIDP
Scientist and Program Official, the External Evaluation Committee and the $\mathrm{CC}$ at City of Hope $(\mathrm{COH})$. The IIDP CC integrates an interactive group of academic laboratories including the subcontracted IIDP centers.

- IIDP Coordinating Center (CC): Joyce Niland, Ph.D. and Carmella EvansMolina, M.D., Ph.D. serve as Co-Principal Investigators (Co-PIs) for the IIDP Program located within the Department of Diabetes and Cancer Discovery Science at $\mathrm{COH}$ to coordinate the activities of the IIDP and Human Islet Phenotyping Program (HIPP). Dr. Niland, contact PI, oversees the daily activity of the IIDP staff, provides informatics/ biostatistical input, and subcontracts with the Islet Isolation Centers (IICs) to ensure the delivery of the highest quality human islets to IIDP-approved investigators. Dr. Evans-Molina serves as the liaison to the HIPP, interacting closely to ensure that extensive, high quality phenotypic data are collected on islets distributed by the IICs. She also facilitates the delivery of this information to both the IICs and the IIDP-approved investigators, while responding to questions, issues, or suggestions for further HIPP enhancements.

- Human Islet Phenotyping Program (HIPP): The HIPP is a subcontracted entity of the IIDP through the $\mathrm{COH}$ and Vanderbilt University. The HIPP is directed by Marcela Brissova, Ph.D. and is responsible for performing specific standardized phenotyping assays agreed upon by both the IIDP and the HIPP, in order to provide enhanced, quality data on the human islets post-shipment, to the IIDP. The results of these assays will be approved by the $\mathrm{CC}$ and posted on the IIDP website for both the centers and the approved investigators.

- Cryosections: Sections of a tissue/cells embedded in optimal cutting temperature (OCT) compound and frozen $8^{\circ}-80^{\circ} \mathrm{C}$

- Indirect Immunofluorescence Staining: Immunohistochemical procedure based on antigen detection by flourescence in histological sections using a combination of primary and secondary antibodies where the primary antibody is directed to the antigen of interest and the fluorescently-conjugated secondary recognizes species where the primary antibody was raised. Histological sections are viewed using a microscope system equipped with an appropriate light source and filter set to allow for visualization of fluorescence tissue staining.

\section{References:}




\section{CITATION}

Dai C, Brissova M, Hang Y, Thompson C, Poffenberger G, Shostak A, et al. Islet-enriched gene expression and glucose-induced insulin secretion in human and mouse islets.

Diabetologia. 2012 Mar;55(3):707-18. PMCID: PMC3268985.

LINK

https://pubmed.ncbi.nlm.nih.gov/22167125/

\section{CITATION}

Guo S, Dai C, Guo M, Taylor B, Harmon JS, Sander M, et al. Inactivation of specific $\beta$ cell transcription factors in type 2 diabetes. J Clin Invest. 2013 Aug;123(8):3305-16. PMCID: PMC3726150.

LINK

https://pubmed.ncbi.nlm.nih.gov/23863625/

\section{MATERIALS}

1. PBS (phosphate buffered saline) with no $\mathrm{Ca} / \mathrm{Mg}, 1 \mathrm{X}$ (Invitrogen 14190-144)

2. BSA (bovine serum albumin, Sigma A-6003)

3. SlowFade Gold (Molecular Probes S36938)

4. Triton X-100 (BioRad 1610407)

5. Normal Donkey Serum (NDS, Jackson Immuno Research 017-000-121)

6. 4',6-diamidino-2-phenylindole (DAPI, ThermoFisher Scientific D1306)

7. Kartell Staining Chambers (VWR 25460-907)

8. PAP Marker (Research Products International 195506)

9. $8^{\circ} 4^{\circ} \mathrm{C}$ Refrigerator (ArcticTemp)

89 PBS (phosphate buffered saline) with no $\mathrm{Ca} / \mathrm{Mg} 1 \mathrm{X}$ Thermo Fisher Scientific Catalog \#Invitrogen 14190-144

88 BSA (bovine serum albumin) Merck MilliporeSigma (Sigma-Aldrich) Catalc \#A-6003

$8 \%$ SlowFade Gold (Molecular Probes) Thermo Fisher Scientific Catalog \#S36938

88 Triton X-100 Bio-Rad Laboratories Catalog \#1610407

89 Normal Donkey Serum Jackson ImmunoResearch Laboratories, Inc. Catalog \#017-000-121 
88 4, 6-diamidino-2-phenylindole (DAPI) Thermo Fisher Scientific Catalog \#D1306

\section{Equipment}

Kartell Staining Chambers

VWR

BRAND

25460-907

SKU

https://us.vwr.com/store/product/4619254/vwr-staining-jar-with-coverhellendhal-type

\section{Equipment}

Marker

PAP

BRAND

195506

SKU

https://www.rpicorp.com/products/molecular-biology/hybridization/superht-mini-pap-pen-2-5mm.html 


\section{Equipment}

$4^{\circ} \mathrm{C}$ Refrigerator

ArcticTemp

None

https://www.meatprocessingproducts.com/arctic-air-commercialrefrigerators.html?gclid=EAlalQobChMI-IzMrrKo7gIVAoiGCh2zAxFEAAYASAAEgJWDvD_BwE

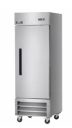

\section{SAFETY WARNINGS}

(1) Triton X-100 (BioRad 1610407)

Safety information

(c) Triton X-100.pdf

\section{Preparation of Reagents}

1 Preparation of Reagents for Immunofluorescence Staining of Islet Cryosections

$1.1 \quad 10 \%$ Triton $X-100$ stock ( \& $30 \mathrm{~mL}$ ) - combine \& $3 \mathrm{~mL}$ Triton- $X-100$ and \& $27 \mathrm{~mL}$ 1X PBS. Mix on shaker for 30 min or until Triton X-100 is completely dissolved and store at $8^{\circ} 4{ }^{\circ} \mathrm{C}$ for up to 1 month. 
1.2 Permeabilization Solution (0.2\% Triton, \& $50 \mathrm{~mL}$ ) - combine \& $1 \mathrm{~mL}$ of $10 \%$ Triton stock and I $49 \mathrm{~mL} 1 \mathrm{X}$ PBS.

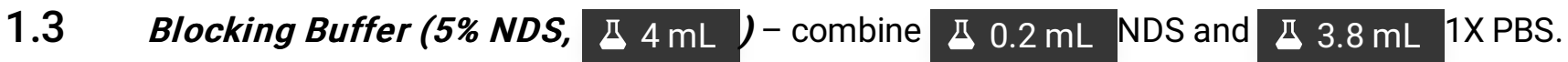

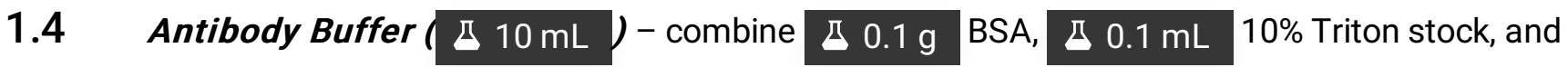
\ $9.8 \mathrm{~mL}$ 1X PBS.

1.5 DAPI staining solution (1:25,000, \& $50 \mathrm{~mL})$ - combine $\triangle 2 \mu \mathrm{L}$ DAPI stock $(5 \mathrm{mg} / \mathrm{mL})$ and $\triangle 50 \mathrm{~mL} 1 \mathrm{XPBS}$.

\section{Procedure}

$2 \quad$ Immunofluorescence Staining Procedure on Islet Cryosections

2.1 Use freshly-made antibody incubation buffers, and wash buffers. Steps $2.3,2.4,2.8,2.10,2.11$ can be done in Kartell Staining Chambers.

2.2 Let the frozen sections thaw at room temperature and air-dry for about 30 minutes.

2.3 Wash the sections with $\triangle 50 \mathrm{~mL}$ 1X PBS 3 times for 5 minutes to remove the OCT. 
2.4 Permeablize the tissue section with $0.2 \%$ Triton for 15 minutes at room temperature.

2.5 Wash the tissue in $\triangle 50 \mathrm{~mL} 1 \mathrm{X}$ PBS 3 times for 3-5 minutes.

2.6 Draw circles or rectangles around the sections with PAP marker and let them dry for about 5 minutes.

2.7 Block the sections with 5\% normal donkey serum (made from 100\% stock)/1X PBS at room temperature for 90 minutes in a humidified chamber.

2.8 Aspirate the blocking solution, add primary antibodies (Table 1) diluted in $0.1 \%$ Triton-X-100 (made from 10\% Triton stock)/1\% BSA/1X PBS and incubate in a humidified chamber overnight at $8^{\circ} 4{ }^{\circ} \mathrm{C}$

Table 1. List of primary and secondary antibodies for assessment of islet cell composition and endocrine/acinar cell composition 


\begin{tabular}{|c|c|c|c|c|c|c|c|}
\hline $\begin{array}{l}\text { Primary } \\
\text { Antibody }\end{array}$ & Vendor & Product number & $\begin{array}{l}\text { Final } \\
\text { Dilution }\end{array}$ & $\begin{array}{l}\text { Secondary } \\
\text { Antibody }\end{array}$ & Vendor & Product number & $\begin{array}{l}\text { Final } \\
\text { Dilution }\end{array}$ \\
\hline \multirow[t]{2}{*}{$\begin{array}{l}\text { C-peptide } \\
\text { (rat) }\end{array}$} & \multirow[t]{2}{*}{$\begin{array}{l}\text { Developmental } \\
\text { Studies } \\
\text { Hybridoma } \\
\text { Bank }\end{array}$} & \multirow[t]{2}{*}{$\begin{array}{l}\text { GN-ID4 } \\
\text { RRID:AB_2631151 }\end{array}$} & \multirow[t]{2}{*}{$1: 100$} & $\begin{array}{l}\text { Rat IgG- } \\
\text { Cy2 } \\
\text { (donkey) }\end{array}$ & $\begin{array}{l}\text { Jackson } \\
\text { ImmunoResearch }\end{array}$ & $\begin{array}{l}712-225-150 \\
\text { RRID:AB_2340673 }\end{array}$ & $1: 500$ \\
\hline & & & & $\begin{array}{l}\text { Rat IgG- } \\
\text { Cy5 } \\
\text { (donkey) }\end{array}$ & $\begin{array}{l}\text { Jackson } \\
\text { ImmunoResearch }\end{array}$ & $\begin{array}{l}712-175-150 \\
\text { RRID:AB_2340671 }\end{array}$ & $1: 200$ \\
\hline $\begin{array}{l}\text { Glucagon } \\
\text { (mouse) }\end{array}$ & Abcam & $\begin{array}{l}\text { ab10988 } \\
\text { RRID:AB_297642 }\end{array}$ & $1: 250$ & $\begin{array}{l}\text { Mouse } \\
\text { IgG-Cy3 } \\
\text { (donkey) }\end{array}$ & $\begin{array}{l}\text { Jackson } \\
\text { ImmunoResearch }\end{array}$ & $\begin{array}{l}715-165-150 \\
\text { RRID:AB_2340813 }\end{array}$ & $1: 500$ \\
\hline $\begin{array}{l}\text { Glucagon } \\
\text { (rabbit) }\end{array}$ & $\begin{array}{l}\text { Cell Signaling } \\
\text { Technology }\end{array}$ & $\begin{array}{l}2760 S \\
\text { RRID:AB_659831 }\end{array}$ & $1: 100$ & $\begin{array}{l}\text { Rabbit } \\
\text { IgG-Cy5 } \\
\text { (donkey) }\end{array}$ & $\begin{array}{l}\text { Jackson } \\
\text { ImmunoResearch }\end{array}$ & $\begin{array}{l}711-175-152 \\
\text { RRID:AB_2340607 }\end{array}$ & $1: 200$ \\
\hline $\begin{array}{l}\text { Somatostatin } \\
\text { (goat) }\end{array}$ & $\begin{array}{l}\text { Santa Cruz } \\
\text { Biotechnology }\end{array}$ & $\begin{array}{l}\text { SC-7819 } \\
\text { RRID:AB_2302603 }\end{array}$ & $1: 500$ & $\begin{array}{l}\text { Goat } \\
\text { IgG-Cy5 } \\
\text { (donkey) }\end{array}$ & $\begin{array}{l}\text { Jackson } \\
\text { ImmunoResearch }\end{array}$ & $\begin{array}{l}705-175-147 \\
\text { RRID:AB_2340415 }\end{array}$ & $1: 200$ \\
\hline $\begin{array}{l}\text { HPX1 } \\
\text { (mouse) }\end{array}$ & $\begin{array}{l}\text { Novus } \\
\text { Biologicals }\end{array}$ & $\begin{array}{l}\text { NBP1-18951 } \\
\text { RRID:AB_1625456 }\end{array}$ & $1: 100$ & $\begin{array}{l}\text { Mouse } \\
\text { IgG-Cy3 } \\
\text { (donkey) }\end{array}$ & $\begin{array}{l}\text { Jackson } \\
\text { ImmunoResearch }\end{array}$ & $\begin{array}{l}715-165-150 \\
\text { RRID:AB_2340813 }\end{array}$ & $1: 500$ \\
\hline
\end{tabular}

Note

\section{Antibody Information}

\section{Primary Antibodies:}

C-peptide (rat): GN-ID4 RRID:AB_2631151

Glucagon (mouse): ab10988 RRID:AB_297642

Glucagon (rabbit): 2760S RRID:AB_659831

Somatostatin (goat): sc-7819 RRID:AB_2302603

HPX1 (mouse): NBP1-18951, RRID:AB_1625456

\section{Secondary Antibodies:}

Rat IgG-Cy2 (donkey): 712-225-150 RRID:AB_2340673

Rat IgG-Cy5 (donkey): 712-175-150 RRID:AB_2340671

Mouse IgG-Cy3 (donkey): 715-165-150 RRID:AB_2340813

Rabbit IgG-Cy5 (donkey): 711-175-152 RRID:AB_2340607

Goat IgG-Cy5 (donkey): 705-175-147 RRID:AB_2340415

Mouse IgG-Cy3 (donkey): 715-165-150 RRID:AB_2340813 
2.9 Aspirate the primary antibodies and wash the sections with $1 \mathrm{X}$ PBS three times for 10 minutes each.

2.10 Add secondary antibodies (Table 1) diluted in $0.1 \%$ Triton/1\% BSA/1X PBS and incubate for 1.5 hours at room temperature in a humidified chamber.

2.11 Aspirate the secondary antibody and counterstain slides with 1:25,000 DAPI/PBS for 10 minutes at room temperature.

2.12 Remove from DAPI and wash the sections with 1X PBS three times for 15 minutes each.

2.13 Mount the sections with SlowFade Gold mounting medium.

\section{Imaging and Analysis}

\section{$3 \quad$ Imaging and Analysis of Fluorescently Labeled Islet Cryosections}

3.1 Capture images of islet sections using a high-resolution whole slide scanning system (ScanScope FL, Aperio/Leica) connected to a web-based digital slide repository powered by eSlide Manager and housed in the Vanderbilt University Medical Center data center (examples of islet images are shown in Figures 1 and 2). 

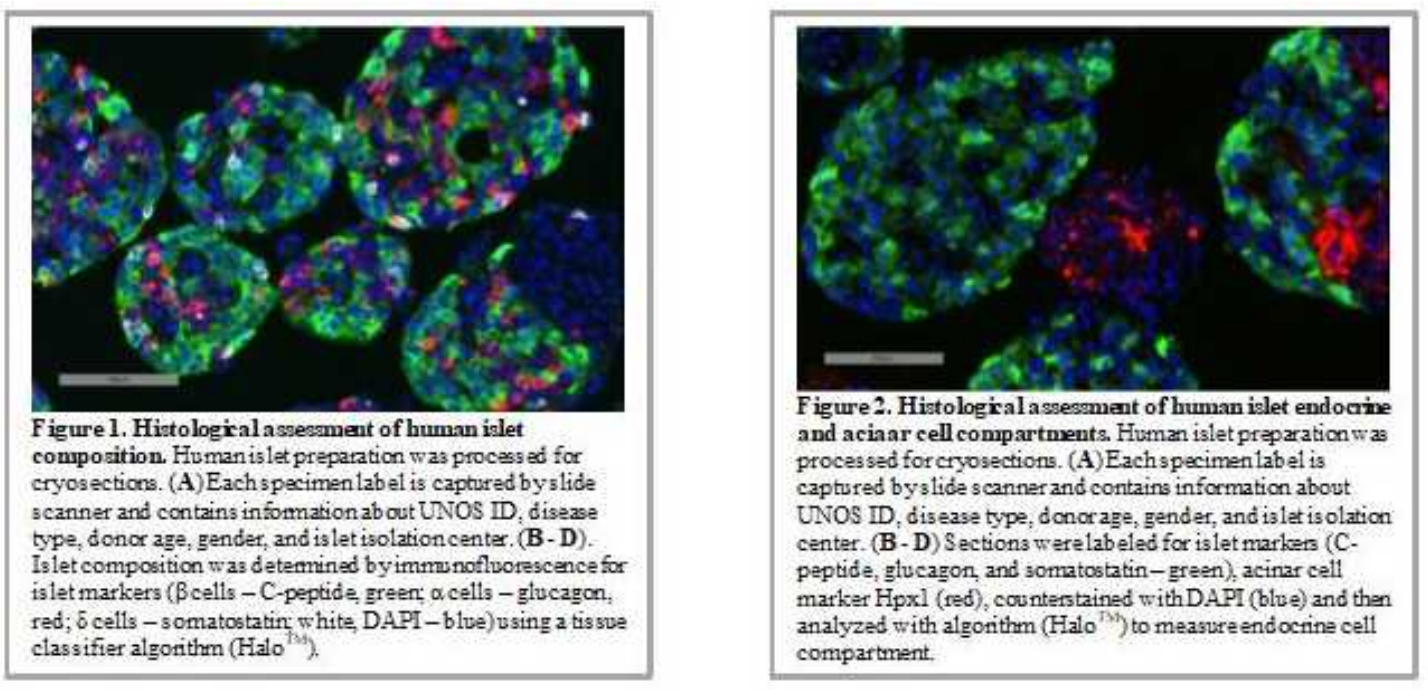

3.2 Using a tissue classifier algorithm ( Halo $^{\mathrm{TM}}$, Indica Labs) analyze islet images (50 -100 islets/labeling experiment) to provide a quantitative assessment of the islet cell composition and endocrine/acinar cell compartments for a given human islet preparation (examples of quantitative islet assessment are shown in the legend of Figures $\mathbf{1}$ and 2).

\section{Data Storage and Reporting}

\section{$4 \quad$ Data Storage and Reporting}

4.1 To facilitate data management and ensure data security, the Vanderbilt HIPP uses an institutional server-based platform for data storage and analysis.

4.2 Upon analysis completion (within 14 business days) annotated images containing metadata and image analysis outputs will be uploaded to the IIDP-HIPP database and immediately disseminated to IIDP-affiliated investigators and islet isolation centers. 